\title{
PROPERTIES OF CONCRETE INCORPORATED WITH GGBS
}

\author{
Ishwar Chandra Thakur ${ }^{1}$, N.Kisku ${ }^{2}$, J.P.Singh ${ }^{3}$, Sheo Kumar ${ }^{4}$ \\ ${ }^{1}$ M.Tech. Scholar, Structural Engineering, Civil Engineering Department, B.I.T. Sindri, Jharkhand, India \\ ${ }^{2}$ Assistant Professor, Civil Engineering Department, B.I.T. Sindri, Jharkhand, India \\ ${ }^{3}$ Associate Professor, Civil Engineering Department, B.I.T. Sindri, Jharkhand, India \\ ${ }^{3}$ Associate Professor, Civil Engineering Department, B.I.T. Sindri, Jharkhand, India
}

\begin{abstract}
Throughout the world, the most widely used construction material is concrete. It is the second most consumed substance on the earth after water. As concrete being used for construction of most of the buildings, bridges etc., it has been labelled as the backbone to the infrastructure development of nation. It is commonly made by mixing Portland cement with sand, crushed rock and water. It is very clear that among the all components, aggregate and water is largely available material in India at very low cost. As cement is comparatively high cost it would be advisable to use other locally available industrial and agricultural waste material to replace the cement partially. Ground Granulated Blast-furnace Slag (GGBS) is a non-metallic and non-hazardous waste material of Iron Industry. Therefore the minimization of this waste material without a harmful effect on nature has a vital importance.The present work focused on the utilization of GGBS in concrete which can be suitably used under the Indian conditions. For this purpose, the various tests on properties of green and hardened concrete have been performed. The properties of green concrete have been analyzed by workability of concrete in terms of slump value whereas the properties of hardened concrete have been analyzed in terms of mechanical and physical properties of concrete. The mechanical properties of hardened concrete include the compressive strength, flexural strength and split tensile strength whereas physical properties includes the dry \& moist density and water absorption of hardened concrete. On the basis of present work we found that GGBS in concrete improves workability, compressive strength, flexural strength, split tensile strength and decreases the density \& water absorption characteristics of hardened concrete. As a result the cost of concrete decreases. Also GGBS leads to the significant reduction in the quantity of cement which enables the reduction in $\mathrm{CO}_{2}$ emission and reduction in energy consumption in production of cement.
\end{abstract}

Keywords: GGBS, cement, fine and coarse aggregate and concrete

\section{INTRODUCTION}

Ground granulated blast furnace slag (GGBS) is a sustainable material which helps in greener environment by reducing the energy consumption and carbon dioxide $\left(\mathrm{CO}_{2}\right)$ gas emission. Only cement industry accounts for around $5 \%$ global carbon dioxide emissions. It emits $\mathrm{CO}_{2}$ gases both directly and indirectly. Direct emission of $\mathrm{CO}_{2}$ occurs through the chemical process called calcination whereas burning of fossil fuels to heat the kiln indirectly results in $\mathrm{CO}_{2}$ gas emission. It has been reported that the manufacture of one tonne of Portland cement would require approximately 1.5 tonnes of mineral extractions together with $5000 \mathrm{MJ}$ of energy, and would generate 0.95 tonne of $\mathrm{CO}_{2}$ equivalent [18]. As GGBS is a by-product of iron manufacturing industry, it is reported that the production of one tonne of GGBS would generate only about 0.07 tonne of $\mathrm{CO}_{2}$ equivalent and consume only about $1300 \mathrm{MJ}$ of energy [18].

GGBS is obtained from iron manufacturing industries, when Silicate and aluminate impurities from ore and coke are combined with flux lowered the viscosity of slag. Molten iron is then tapped off, the remaining molten slag, which consists of mainly siliceous and aluminous residue, is then water-quenched rapidly below $800^{\circ} \mathrm{C}$ in order to prevent the crystallization of merwinite and melilite, resulting in the formation of a glassy granulate. This glassy granulate is then dried and grounded into fine powder, which is known as ground granulated blast furnace slag (GGBS). The main component of blast furnace slag are $\mathrm{CaO}$ (30-50\%), $\mathrm{SiO}_{2}$ (30-40\%), $\mathrm{Al}_{2} \mathrm{O}_{3}(8-24 \%)$ and $\mathrm{MgO}(1-18 \%)$ which is close to the chemical composition of portland cement. It is commonly used in combination with portland cement in concrete for many applications. Concrete made with GGBS has many advantages, including improved strength $[5,6,13,16]$, durability $[3,9,13]$, workability $[1,2,19]$, economic and environmental benefits [9]. The only drawback in the use of GGBS concrete is that its strength development is considerably slower under the standard curing conditions than that of portland cement concrete, although the ultimate strength is higher for the same waterbinder ratio $[2,3,16]$. In the construction of large structural concrete elements where heat dissipation is slow, there can be a significant rise in temperature within the first few days after casting due to the exothermic reaction of the binder [4].

The main objective of the present work is to develop a high performance concrete (HPC) by the use of GGBS. Therefore, the experimental program has been undertaken with the objectives to check the compressive, tensile and flexural strength of concrete grade M30. In addition to this the density and water absorption characteristics of hardened concrete was also evaluated. In whole of the experimental works cement was partially replaced by $10 \%, 20 \%, 30 \%$, $40 \%, 50 \%, 60 \%$ and $70 \%$ GGBS. 


\section{MATERIAL USED}

The materials used in experimental investigation include:

\subsection{Cement}

Ordinary Portland cement of 43-grade conforming to IS: 8112-1989 was used in this project under the brand name Reliance Cement.

\subsection{GGBS}

Ground Granulated Blast-furnace Slag (GGBS) used in this project is the mixed slag from Tata Steel, Jamshedpur and Electro Steel Chandankyari, Dhanbad, Jharkhand. The physical \& mechanical properties of cement and GGBS are given in table 1 .

Table-1: Physical \& mechanical properties of cement\& GGBS

\begin{tabular}{|l|l|l|}
\hline Test & Cement & GGBS \\
\hline Color & Gray & Off white \\
\hline Consistency & $25 \%$ & $33 \%$ \\
\hline Soundness & $4 \mathrm{~mm}$ & -- \\
\hline Initial setting time & 110 minutes & -- \\
\hline Final setting time & 290 minutes & -- \\
\hline Specific gravity & 3.13 & 2.95 \\
\hline Fineness (sieving on $90 \mu \mathrm{m})$ & $8.5 \%$ & $0 \%$ \\
\hline Fineness (Blain's air & $302 \mathrm{~m}^{2} / \mathrm{kg}$ & $320 \mathrm{~m}^{2} / \mathrm{kg}$ \\
permeability) & $1.48 \mathrm{gm} / \mathrm{cm}^{3}$ & $1.29 \mathrm{gm} / \mathrm{cm}^{3}$ \\
\hline Bulk density & $\mathrm{N} / \mathrm{mm}^{2}$ & \\
\hline $\begin{array}{l}\text { Compressive strength } \\
\text { 3days }\end{array}$ & 23.33 & -- \\
7days & 34.33 & -- \\
28 days & 46.18 & -- \\
\hline
\end{tabular}

\section{Chemical Properties}

The test for Chemical Properties of Cement \& GGBS has been performed using X-Ray Fluorescence Machine at ACC Plant Sindri. The result of which are given in table 2.

Table-2: Chemical Properties of Cement \& GGBS

\begin{tabular}{|l|l|l|}
\hline Chemical Composition & Cement & GGBS \\
\hline $\mathrm{CaO}$ & 63.20 & 35.27 \\
\hline $\mathrm{SiO}_{2}$ & 21.06 & 34.72 \\
\hline $\mathrm{Al}_{2} \mathrm{O}_{3}$ & 5.72 & 19.11 \\
\hline $\mathrm{MgO}$ & 1.90 & 8.46 \\
\hline $\mathrm{Fe}_{2} \mathrm{O}_{3}$ & 4.38 & 0.5 \\
\hline $\mathrm{SO}_{3}$ & 2.04 & 0.18 \\
\hline $\mathrm{Na}_{2} \mathrm{O}$ & 0.25 & 0.16 \\
\hline $\mathrm{K}_{2} \mathrm{O}$ & 0.87 & 0.58 \\
\hline $\mathrm{Cl}$ & 0.01 & 0.01 \\
\hline $\mathrm{TiO}_{2}$ & 0.40 & 0.65 \\
\hline $\mathrm{P}_{2} \mathrm{O}_{5}$ & 0.09 & 0.01 \\
\hline $\mathrm{Mn}_{2} \mathrm{O}_{3}$ & 0.07 & $0.14(\mathrm{MnO})$ \\
\hline $\mathrm{Glass}_{2}$ Content & -- & 95 \\
\hline
\end{tabular}

\subsection{Fine and Coarse Aggregate}

The aggregate passing through the sieve size $4.75 \mathrm{~mm}$ is termed as fine aggregate and those which retained on 4.75 $\mathrm{mm}$ sieve is termed as coarse aggregate. River sand obtained from Barakar River were used as fine aggregate whereas mechanically crushed angular coarse aggregate from a quarry situated in Baliyapur, Dhanbad were used coarse aggregate. All the properties of aggregates were tested in accordance with IS: 2386 (part I to IV) -1963 and the results obtained were confirmed with IS 383-1970. Table 3 summarizes the properties of fine and coarse aggregate.

Table-3: Properties of fine and coarse aggregate

\begin{tabular}{|l|l|l|}
\hline Test & $\begin{array}{l}\text { Fine } \\
\text { Aggregate }\end{array}$ & Coarse Aggregate \\
\hline Zone/type & II & Crushed angular \\
\hline $\begin{array}{l}\text { Free (surface) } \\
\text { moisture }\end{array}$ & $0.60 \%$ & $0.20 \%$ \\
\hline $\begin{array}{l}\text { Water } \\
\text { Absorption }\end{array}$ & $1.10 \%$ & $0.45 \%$ \\
\hline $\begin{array}{l}\text { Fineness } \\
\text { Modulus }\end{array}$ & 2.78 & $\begin{array}{l}7.25(\text { fraction I- } 20 \mathrm{~mm}) \\
6.29(\text { fraction II- } 10 \mathrm{~mm})\end{array}$ \\
\hline Specific gravity & 2.62 & 2.89 \\
\hline $\begin{array}{l}\text { Unit } \\
\text { weight(Compact) }\end{array}$ & $1.63 \mathrm{gm} / \mathrm{cc}$ & $1.90 \mathrm{gm} / \mathrm{cc}$ \\
\hline $\begin{array}{l}\text { Unit } \\
\text { weight(Loose) }\end{array}$ & $1.58 \mathrm{gm} / \mathrm{cc}$ & $1.67 \mathrm{gm} / \mathrm{cc}$ \\
\hline
\end{tabular}

\subsection{Water}

Water which is suitable for drinking is satisfactory for use in concrete. It was tested and checked for permissible limit as per the IS: 3025 and IS: 456-2000. Properties of water as obtained are given in table 4.

Table-4: Properties of water

\begin{tabular}{|l|l|l|}
\hline Solids & Result & Permissible Limit \\
\hline Organic & $55 \mathrm{mg} / \mathrm{l}$ & $200 \mathrm{mg} / \mathrm{l}$ \\
\hline Inorganic & $1200 \mathrm{mg} / \mathrm{l}$ & $3000 \mathrm{mg} / \mathrm{l}$ \\
\hline Sulphate $\left(\mathrm{SO}_{3}\right)$ & $75 \mathrm{mg} / \mathrm{l}$ & $400 \mathrm{mg} / \mathrm{l}$ \\
\hline Chloride $(\mathrm{Cl})$ & $1150 \mathrm{mg} / \mathrm{l}$ & $\begin{array}{l}2000 \mathrm{mg} / \mathrm{l} \text { for P.C.C. } \\
500 \mathrm{mg} / \mathrm{l} \text { for R.C.C. }\end{array}$ \\
\hline Suspended matter & $510 \mathrm{mg} / \mathrm{l}$ & $2000 \mathrm{mg} / \mathrm{l}$ \\
\hline $\mathrm{pH}$ & 6.8 & $>6$ \\
\hline
\end{tabular}

\section{EXPERIMENTAL PROCEDURE}

Experimental procedure has been described in the following paragraphs.

\subsection{Mix Design}

Proportioning of concrete mix for M30 grade of concrete has been achieved by concrete mix design as per IS 10262:2009. Composition of constituent material per cubic meter of concrete for different batches is given in table 5 . 
Table-5: Proportioning of the concrete mix

\begin{tabular}{|l|l|l|l|l|l|l|l|}
\hline $\begin{array}{l}\text { Mix } \\
\text { Desig } \\
\text { nation }\end{array}$ & $\begin{array}{l}\text { Cem } \\
\text { ent } \\
\%\end{array}$ & $\begin{array}{l}\text { GG } \\
\text { BS }\end{array}$ & $\begin{array}{l}\text { Wate } \\
(\mathrm{Kg})\end{array}$ & $\begin{array}{l}\text { Cem } \\
\text { ent } \\
(\mathrm{Kg})\end{array}$ & $\begin{array}{l}\text { GGB } \\
\mathrm{S} \\
(\mathrm{Kg})\end{array}$ & $\begin{array}{l}\mathrm{FA} \\
(\mathrm{Kg})\end{array}$ & $\begin{array}{l}\mathrm{CA} \\
(\mathrm{Kg})\end{array}$ \\
\hline $\mathrm{R}_{0}$ & 100 & 0 & 188 & 425 & 0 & 653 & 1236 \\
\hline $\mathrm{R}_{10}$ & 90 & 10 & 188 & 383 & 42 & 653 & 1236 \\
\hline $\mathrm{R}_{20}$ & 80 & 20 & 188 & 340 & 85 & 653 & 1236 \\
\hline $\mathrm{R}_{30}$ & 70 & 30 & 188 & 298 & 127 & 653 & 1236 \\
\hline $\mathrm{R}_{40}$ & 60 & 40 & 188 & 255 & 170 & 653 & 1236 \\
\hline $\mathrm{R}_{50}$ & 50 & 50 & 188 & 213 & 212 & 653 & 1236 \\
\hline $\mathrm{R}_{60}$ & 40 & 60 & 188 & 170 & 255 & 653 & 1236 \\
\hline $\mathrm{R}_{70}$ & 30 & 70 & 188 & 127 & 298 & 653 & 1236 \\
\hline
\end{tabular}

\subsection{Mixing Technique}

Hand mixing technique has been adopted in the whole experimental work at temperature of $27^{\circ} \pm 2^{\circ} \mathrm{C}$ and relative humidity 90 percent. In each batch 6 specimen of cube of dimension $150 \mathrm{~mm} \times 150 \mathrm{~mm} \times 150 \mathrm{~mm}, 6$ specimen of cylinder of dimension $150 \mathrm{~mm}$ diameter x $300 \mathrm{~mm}$ height, and 3 specimen of beam of dimension $100 \mathrm{~mm} \times 100 \mathrm{~mm} \times$ $500 \mathrm{~mm}$ has been made.

\subsection{Properties of Fresh Concrete}

The property of fresh concrete has been assessed by workability in terms of slump value. The test of which has been performed in accordance with IS 1199:1959. The results of which are given below in table 6 .

Table-6: Slump test of concrete

\begin{tabular}{|l|l|l|l|l|l|l|l|l|}
\hline $\begin{array}{l}\text { Mix } \\
\text { type }\end{array}$ & $\mathrm{R}_{0}$ & $\mathrm{R}_{10}$ & $\mathrm{R}_{20}$ & $\mathrm{R}_{30}$ & $\mathrm{R}_{40}$ & $\mathrm{R}_{50}$ & $\mathrm{R}_{60}$ & $\mathrm{R}_{70}$ \\
\hline $\begin{array}{l}\text { Slump } \\
(\mathrm{mm})\end{array}$ & 60 & 63 & 65 & 68 & 70 & 73 & 71 & 67 \\
\hline
\end{tabular}

From above table, it is observed that the slump value of concrete increases as the percentage of GGBS increases up to $50 \%$ replacement and then decreases. The increase in slump value is due to the higher smoothness and fineness of slag increases the entrainment of air in the matrix, subsequently increasing the volume of paste.

\subsection{Properties of Hardened Concrete}

Hardened concrete properties have been analyzed in the terms of compressive, flexural \& split tensile strength, dry \& moist density and water absorption. As the development of strength is time dependent hence these tests has been performed after a different curing period. One sample each of cube and cylinder has been tested at 7 and 28 days for compressive strength and split tensile strength of concrete respectively while the beam has been tested after curing period of 28 days for flexural strength of concrete.

\section{Compressive Strength}

This test was performed in accordance with IS 516:1959 on the cube of size $150 \mathrm{~mm} \times 150 \mathrm{~mm} \times 150 \mathrm{~mm}$. The result of which is given below in table 7 .

Table-7: Compressive strength of concrete

\begin{tabular}{|c|c|c|c|c|}
\hline \multirow{2}{*}{$\begin{array}{l}\text { Mix } \\
\text { type }\end{array}$} & \multicolumn{2}{|l|}{7 days } & \multicolumn{2}{|l|}{28 days } \\
\hline & $\begin{array}{l}\text { Avg. } \\
\text { Compressiv } \\
\text { e Strength } \\
\left(\mathrm{N} / \mathrm{mm}^{2}\right)\end{array}$ & $\begin{array}{l}\% \\
\text { variatio } \\
\text { ns over } \\
\mathrm{R}_{0}\end{array}$ & $\begin{array}{l}\text { Avg. } \\
\text { Compressiv } \\
\text { e Strength } \\
\left(\mathrm{N} / \mathrm{mm}^{2}\right)\end{array}$ & $\begin{array}{l}\% \\
\text { variations } \\
\text { over } \mathrm{R}_{0}\end{array}$ \\
\hline $\mathrm{R}_{0}$ & 26.22 & 0 & 38.74 & 0 \\
\hline $\mathrm{R}_{10}$ & 25.04 & -4.50 & 40.30 & +4.03 \\
\hline $\mathrm{R}_{20}$ & 24.00 & -8.47 & 41.78 & +7.84 \\
\hline $\mathrm{R}_{30}$ & 23.56 & -10.14 & 43.11 & +11.28 \\
\hline $\mathrm{R}_{40}$ & 23.26 & -11.29 & 47.26 & +21.99 \\
\hline $\mathrm{R}_{50}$ & 22.96 & -12.43 & 49.85 & +28.68 \\
\hline $\mathrm{R}_{60}$ & 21.26 & -18.92 & 47.63 & +22.95 \\
\hline $\mathrm{R}_{70}$ & 19.11 & -27.12 & 44.22 & +14.15 \\
\hline
\end{tabular}

Graph showing the variation of compressive strength of concrete with different percentage of GGBS is presented below in figure 1 .

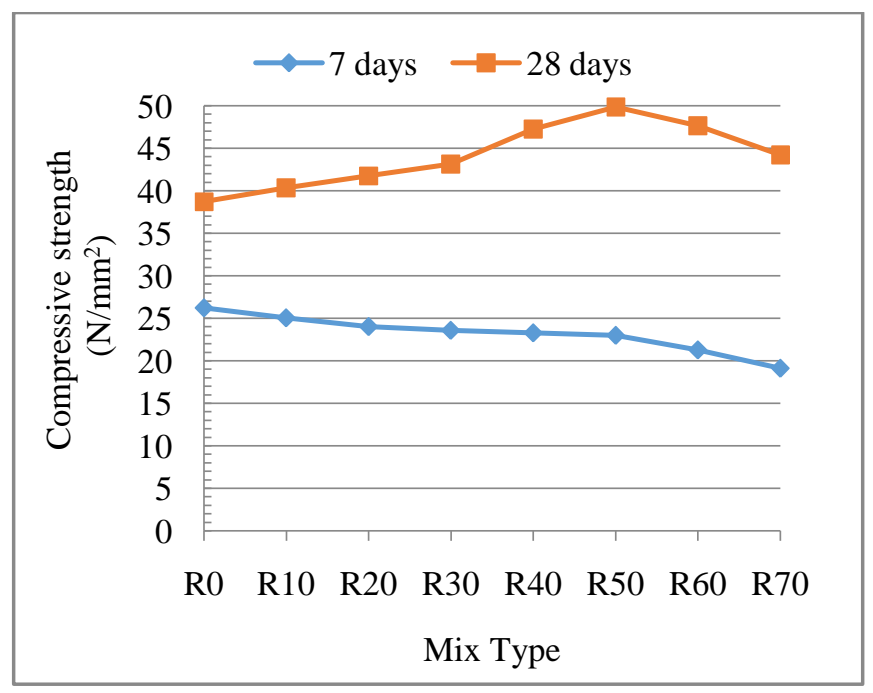

Fig-1: Compressive strength of concrete

From the above fig., it is observed that compressive strength of concrete with increasing percentage of GGBS decreases after 7days but increases after 28 days with optimum percentage of $50 \%$ replacement by GGBS. It indicates the slower rate of reaction of matrix by incorporation of GGBS. At optimum percentage of GGBS the compressive strength is $28.68 \%$ higher than that of conventional cement concrete.

\section{Split Tensile Strength}

This test was performed in accordance with IS 5816:1999 on the cylinder of diameter $150 \mathrm{~mm}$ and height $300 \mathrm{~mm}$. The result of which is given below in table 8 . 
Table-8: Split Tensile Strength of concrete

\begin{tabular}{|c|c|c|c|c|}
\hline \multirow[b]{2}{*}{$\begin{array}{l}\text { Mix } \\
\text { type }\end{array}$} & \multicolumn{2}{|l|}{7 days } & \multicolumn{2}{|l|}{28 days } \\
\hline & $\begin{array}{l}\text { Split tensile } \\
\text { Strength } \\
\left(\mathrm{N} / \mathrm{mm}^{2}\right)\end{array}$ & $\begin{array}{l}\% \\
\text { variation } \\
\text { s over } \mathrm{R}_{0}\end{array}$ & $\begin{array}{l}\text { Split tensile } \\
\text { Strength } \\
\left(\mathrm{N} / \mathrm{mm}^{2}\right)\end{array}$ & $\begin{array}{l}\% \\
\text { variations } \\
\text { over } \mathrm{R}_{0}\end{array}$ \\
\hline $\mathrm{R}_{0}$ & 2.64 & 0.00 & 2.93 & 0.00 \\
\hline $\mathrm{R}_{10}$ & 2.48 & -6.25 & 3.09 & +5.64 \\
\hline $\mathrm{R}_{20}$ & 2.41 & -8.93 & 3.21 & +9.68 \\
\hline $\mathrm{R}_{30}$ & 2.26 & -14.29 & 3.28 & +12.10 \\
\hline $\mathrm{R}_{40}$ & 1.82 & -31.25 & 3.42 & +16.94 \\
\hline$R_{50}$ & 1.72 & -34.82 & 3.51 & +20.16 \\
\hline $\mathrm{R}_{60}$ & 1.51 & -42.86 & 3.59 & +22.58 \\
\hline $\mathrm{R}_{70}$ & 1.37 & -44.76 & 3.47 & +12.21 \\
\hline
\end{tabular}

Graph showing the variation of split tensile strength of concrete with different percentage of GGBS is presented in figure 2 .

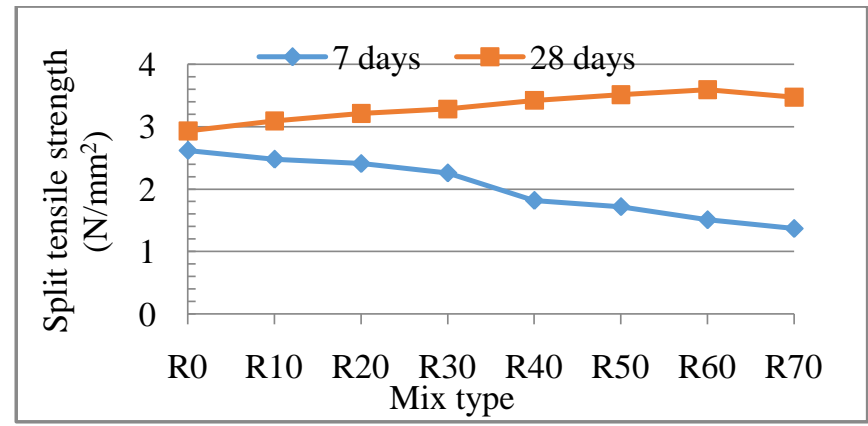

Fig-2: Split tensile strength of concrete

From the fig., it is observed that split tensile strength of concrete with increasing percentage of GGBS decreases after 7days but increases after 28days with optimum percentage of $60 \%$ replacement by GGBS. It indicates the slower rate of reaction of matrix by incorporation of GGBS. At optimum percentage of GGBS the Split tensile strength is $22.58 \%$ higher than that of conventional cement concrete.

\section{Flexural Strength}

This test was performed in accordance with IS 516:1959 on the beam of dimension $100 \mathrm{~mm} \times 100 \mathrm{~mm} \times 500 \mathrm{~mm}$ which were tested at 28 days curing period and average of which were found out. The result of which is given in table 9 .

Table-9: Flexural Strength on concrete

\begin{tabular}{|c|c|c|}
\hline \multirow[b]{2}{*}{ Mix type } & \multicolumn{2}{|l|}{28 days } \\
\hline & $\begin{array}{l}\text { Avg. Flexural } \\
\text { Strength }\left(\mathrm{N} / \mathrm{mm}^{2}\right)\end{array}$ & $\%$ variations over $R_{0}$ \\
\hline $\mathrm{R}_{0}$ & 3.87 & 0.00 \\
\hline $\mathrm{R}_{10}$ & 4.18 & +8.01 \\
\hline $\mathrm{R}_{20}$ & 4.36 & +12.66 \\
\hline $\mathrm{R}_{30}$ & 4.39 & +13.44 \\
\hline $\mathrm{R}_{40}$ & 4.63 & +19.64 \\
\hline $\mathrm{R}_{50}$ & 4.92 & +27.13 \\
\hline $\mathrm{R}_{60}$ & 4.73 & +22.22 \\
\hline $\mathrm{R}_{70}$ & 4.39 & +13.44 \\
\hline
\end{tabular}

Graph showing the variation of flexural strength of concrete with different percentage of GGBS is given in figure 3.

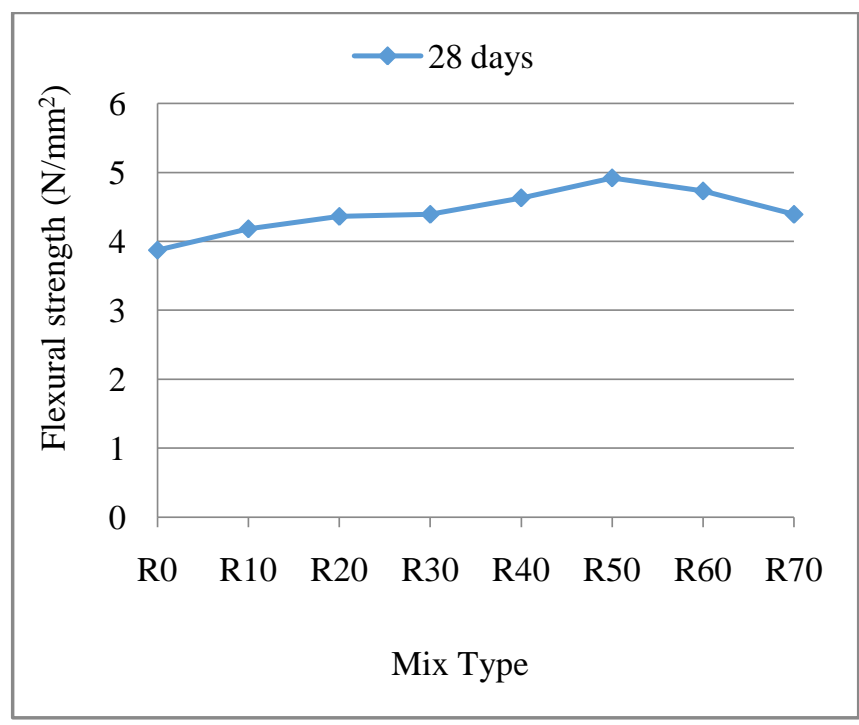

Fig-3: Flexural strength of concrete

From the graph, it may be observed that the flexural strength of concrete with increasing percentage of GGBS increases after 28 days with optimum percentage of $50 \%$ replacement by GGBS. At this stage of replacement of cement with GGBS flexural strength is $27.13 \%$ higher than that of conventional cement concrete.

\section{Dry and Moist Density}

Dry \& moist density of concrete has been determined in accordance with ISO: 6275-1982 and NT BUILD 200. The value of which are given in table 10 .

Table-10: Dry and moist density of hardened concrete

\begin{tabular}{|c|c|c|c|c|}
\hline \multirow[b]{2}{*}{ Mix type } & \multicolumn{2}{|c|}{ Dry Density } & \multicolumn{2}{|c|}{ Moist Density } \\
\hline & $\begin{array}{l}\text { Avg. } \\
\text { density } \\
\left(\mathrm{gm} / \mathrm{cm}^{3}\right)\end{array}$ & $\begin{array}{l}\% \\
\text { variation } \\
\text { over } \mathrm{R}_{0}\end{array}$ & $\begin{array}{l}\text { Avg. } \\
\text { density } \\
\left(\mathrm{gm} / \mathrm{cm}^{3}\right)\end{array}$ & $\begin{array}{l}\% \\
\text { variation } \\
\text { over } \mathrm{R}_{0}\end{array}$ \\
\hline $\mathrm{R}_{0}$ & 2.71 & 0.00 & 2.84 & 0.00 \\
\hline $\mathrm{R}_{10}$ & 2.65 & -2.41 & 2.75 & -3.14 \\
\hline $\mathrm{R}_{20}$ & 2.63 & -3.09 & 2.73 & -3.83 \\
\hline $\mathrm{R}_{30}$ & 2.51 & -7.63 & 2.60 & -8.41 \\
\hline $\mathrm{R}_{40}$ & 2.48 & -8.57 & 2.56 & -9.59 \\
\hline $\mathrm{R}_{50}$ & 2.45 & -9.72 & 2.51 & -11.62 \\
\hline $\mathrm{R}_{60}$ & 2.43 & -10.31 & 2.48 & -12.43 \\
\hline $\mathrm{R}_{70}$ & 2.39 & -12.10 & 2.43 & -14.36 \\
\hline
\end{tabular}

Graph showing the variation of dry and moist density of hardened concrete with different percentage of GGBS is presented in figure 4 . 


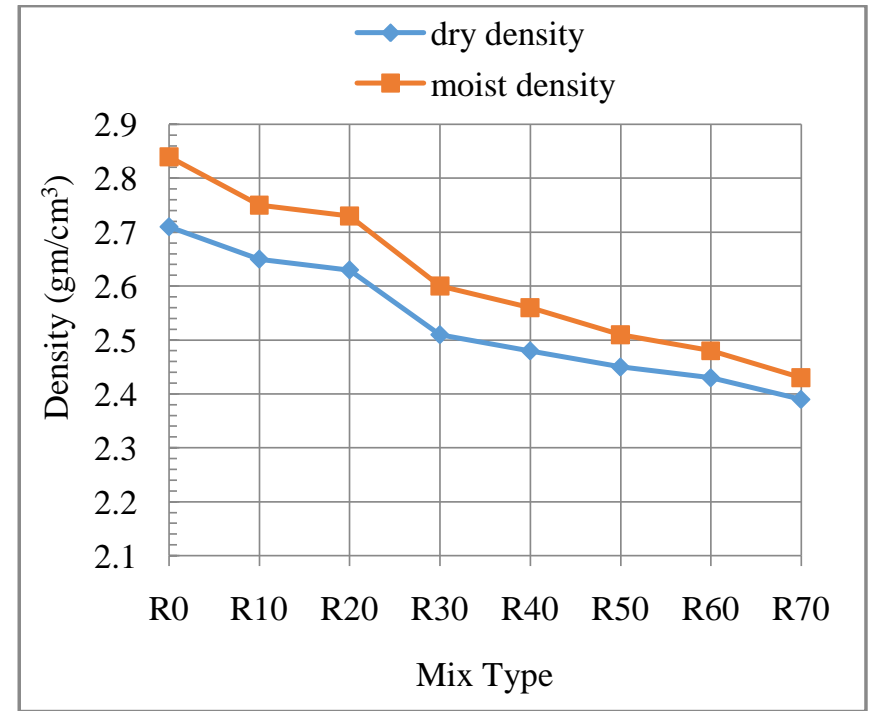

Fig-4: Dry and moist density of hardened concrete

From the above fig., it is observed that the dry and moist density of concrete decreases as the percentage of GGBS increases. From the above results, it is concluded that the GGBS can be used to produce the concrete of lower density.

\section{Water Absorption}

Water absorption of concrete has been determined in accordance with ISO: 6275-1982 and NT BUILD 200. The value of which are given in table 11 .

Table-11: Water Absorption of hardened concrete

\begin{tabular}{|c|c|c|}
\hline Mix type & Avg. water absorption $\%$ & $\%$ variation over $\mathrm{R}_{0}$ \\
\hline $\mathrm{R}_{0}$ & 4.50 & 0.00 \\
\hline $\mathrm{R}_{10}$ & 3.72 & -17.37 \\
\hline $\mathrm{R}_{20}$ & 3.69 & -17.96 \\
\hline $\mathrm{R}_{30}$ & 3.61 & -19.75 \\
\hline $\mathrm{R}_{40}$ & 3.35 & -25.66 \\
\hline $\mathrm{R}_{50}$ & 2.30 & -48.96 \\
\hline $\mathrm{R}_{60}$ & 2.04 & -54.74 \\
\hline $\mathrm{R}_{70}$ & 1.81 & -59.79 \\
\hline
\end{tabular}

Graph showing the variation of water absorption of hardened concrete with different percentage of GGBS is presented in figure 5 .

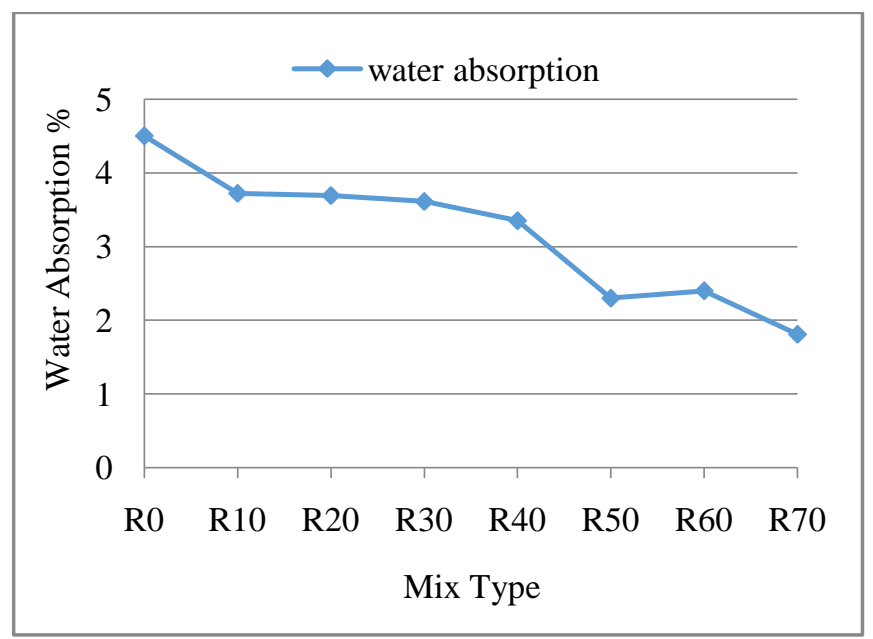

Fig-5: Water absorption of hardened concrete

From the above fig., it is observed that the water absorption of concrete decreases as the percentage of GGBS increases. From this result, it is concluded that the GGBS can be used to improve the water impermeability characteristics of structure. Hence the corrosion of reinforcement may be retarded \& durability of R.C.C. structure may be increased.

\subsection{Cost Analysis}

Material cost estimation includes cost of water, cement, fine aggregate and coarse aggregate for a particular design mix. As per the mix design calculation we obtained that the weight of water, cement, fine aggregate and coarse aggregate are $188 \mathrm{~kg}, 425 \mathrm{~kg}, 653 \mathrm{~kg}$ and $1236 \mathrm{~kg}$ respectively for $1 \mathrm{~m}^{3}$ of dry concrete. As the water is largely available material in India hence its cost can be neglected. Present study shows that the replacement of cement by GGBS can be done as much as $60 \%$ (by weight). Analysis of the cost of concrete with and without GGBS is given below in table 12 .

Table-12: Cost of material per cubic meter of concrete

\begin{tabular}{|c|c|c|c|c|c|c|}
\hline \multirow{2}{*}{ Item name } & \multirow{2}{*}{ Rate } & \multicolumn{2}{|c|}{ Conventional concrete } & \multicolumn{2}{|c|}{ GGBS concrete } & \multirow{2}{*}{$\%$ saving } \\
\hline & & Quantity & Cost & Quantity & Cost & \\
\hline GGBS & $₹ 0.50$ Per kg & --- & --- & $255 \mathrm{~kg}$ & $₹ 128$ & \\
\hline Cement & $₹ 400$ per bag & 8.50 bags & ₹ 3400 & 3.40 bags & ₹ 1360 & \\
\hline Fine aggregate & $₹ 860$ per $\mathrm{m}^{3}$ & $0.249 \mathrm{~m}^{3}$ & $₹ 214$ & $0.249 \mathrm{~m}^{3}$ & $₹ 214$ & \\
\hline \multirow[t]{2}{*}{ Coarse aggregate } & $₹ 2500$ per $\mathrm{m}^{3}$ & $0.428 \mathrm{~m}^{3}$ & ₹ 1070 & $0.428 \mathrm{~m}^{3}$ & ₹ 1070 & \\
\hline & & & $\sum=₹ 4684$ & & $\sum=₹ 2772$ & $40.82 \%$ \\
\hline
\end{tabular}


From the above table, we observe that the use of GGBS in concrete saves money up to $40.82 \%$ over the conventional cement concrete. This is a significant saving of money. Hence GGBS concrete is more economical.

\section{CONCLUSION}

1. Slump value of concrete increases as the percentage of GGBS increases up to $50 \%$ replacement and then decreases. The increase in slump value is due to the higher smoothness and fineness of slag increases the entrainment of air in the matrix, subsequently increasing the volume of paste.

2. Compressive strength of concrete with increasing percentage of GGBS decreases after 7days but increases after 28 days with optimum percentage of $50 \%$ replacement by GGBS. It indicates the slower rate of reaction of matrix by incorporation of GGBS. At optimum percentage of GGBS the compressive strength is $28.68 \%$ higher than that of conventional cement concrete.

3. Split tensile strength of concrete with increasing percentage of GGBS decreases after 7days but increases after 28days with optimum percentage of $60 \%$ replacement by GGBS. It indicates the slower rate of reaction of matrix by incorporation of GGBS. At optimum percentage of GGBS the Split tensile strength is $22.58 \%$ higher than that of conventional cement concrete.

4. Flexural strength of concrete with increasing percentage of GGBS increases after 28 days with optimum percentage of $50 \%$ replacement by GGBS. At this stage of replacement of cement with GGBS flexural strength is $27.13 \%$ higher than that of conventional cement concrete.

5. Dry and moist density of concrete decreases as the percentage of GGBS increases. From the above results, it is concluded that the GGBS can be used to produce the concrete of lower density.

6. Water absorption of concrete decreases as the percentage of GGBS increases. From this results, it is concluded that the GGBS can be used to improve the water impermeability characteristics of structure.Hence the corrosion of reinforcement may be retarded \& durability of R.C.C. structure may be increased.

7. Use of GGBS in concrete saves money up to $40.82 \%$ over the conventional cement concrete. This is a significant saving of money. Hence GGBS concrete is more economical.

\section{ACKNOWLEDGEMENT}

The author is thankful to Dr. V. Pandey, the Head of Civil Engineering Department, for their valuable suggestion and encouragement at various stages of the project work. We are also thankful to Mr. Manoj Kumar Giri, Manager and Quality Head, ACC Plant Sindri for their guidance and cooperation to conduct various tests at their modern technology laboratory.

\section{REFERENCES}

[1] ACI Committee 233 Report, Slag Cement in Concrete and Mortar, ACI 233R-03, American Concrete Institute, Farmington Hills, Mich, 2003.

[2] Duos, C., and Eggers, J., "Evaluation of Ground Granulated Blast Furnace Slag in Concrete (Grade120)", Rpt. No. FHWA/LA-99/336, Louisiana Trans. Res. Center, Baton Rouge, Louisiana, Oct. 1999, $45 \mathrm{p}$.

[3] J. Bijen, "Blast Furnace Slag Cement for Durable Marine Structures", Stichting BetonPrisma, Netherlands, 1996.

[4] J.G. Sanjayan, B. Sioulas, "Strength of slag-cement concrete cured in place and in other conditions", ACI Mater. J. 97 (5) (2000) 603-611.

[5] K. Suvarna Latha, M V Seshagiri Rao, Srinivasa Reddy. V. "Estimation of GGBS and HVFA Strength Efficiencies in Concrete with Age"International Journal of Engineering and Advanced Technology (IJEAT) ISSN: 2249 - 8958, Volume-2, Issue-2, and December 2012.

[6] Li, C., Yoda, A., and Yokomur, T., "Pore Structure, Strength and Carbonation of Cement Pastes Containing Ground Granulated Blast-Furnace Slag," Fly Ash, Silica Fume, Slag and Natural Pozzolana in Concrete, SP 178, American Concrete Institute, Farmington Hills, Mich., 1998, pp. 875-892.

[7] Malhotra, V. M. 1987. "Properties of fresh and hardened concrete incorporating ground granulated blast furnace slag". In Supplementary cementing materials for concrete, ed. V. M. Malhotra, 291-331. Ottawa: Canadian Government Publishing Centre.

[8] Malhotra, V. M. 1983. "Strength and durability characteristics of concrete incorporating a pelletized blast-furnace slag”. In ACI special publication SP-79.

[9] Malhotra, V.M., "Mechanical Properties and Freezing and Thawing Durability of Concrete Incorporating Ground Granulated Blast Furnace Slag," Canadian Journal of Civil Engineering, V. 16, No. 2, 1989, pp. 140-156

[10] MojtabaValinejad Shoubi, Azin Shakiba Barough and Omidreza Amirsoleimani (2013). "Assessment of the Roles of Various Cement Replacements in Achieving Sustainable and High Performance Concrete". International Journal of Advances in Engineering and Technology, 6 (1): 68-77.

[11] Moir, G. K., and J. S. Lumley. 1989. "Influence of partial cement replacement by ground granulated furnace slag on the expansion of concrete prisms containing reactive aggregate". In 9th international conference on alkali-aggregate reaction: Proceedings, 199-204. Kyoto, Japan.

[12] Neville, A. M., "Properties of Concrete", 4th Ed., John Wiley and Sons, Inc., pp.665-666

[13] Peter W.C. Leung, and Wong, H.D. (2010). "Final Report on Durability and Strength Development of Ground Granulated Blast Furnace Slag Concrete". Geotechnical Engineering Office, Civil Engineering and Development Department, the Government of Hong Kong. 
[14] Peterson, N.K., and Hale, M., "The Durability, Permeability, and Strength of Concrete Mixtures Containing Ground Granulated Blast Furnace Slag and Fly Ash," Presentation, ACI National Convent ion, Washington, D.C., 2004.

[15] Rose, J. 1987. "The effect of cementitious blast-furnace slag on chloride permeability of concrete". In ACI special publication SP-102: Corrosion, concrete and chlorides, ed. F. W. Gibson, 107-25. Detroit: American Concrete Institute

[16] Shariq, M., Prasad, J., and Ahuja, A.K. (2008). "Strength Development of Cement Mortar and Concrete Incorporating GGBFS". Asian Journal of Civil Engineering (Building and Housing), 9 (1), 6174.

[17] Scott A, Alexander MG (2007) the influence of binder type, cracking and cover on corrosion rates of steel in chloride contaminated concrete, Mag concr Res 59(7) : 495-505

[18] S. Arivalagan (2014) "Sustainable Studies on Concrete with GGBS As a Replacement Material in Cement", Jordan Journal of Civil Engineering, Volume 8, No. 3, 2014

[19] V.S. Tamilarasan, Dr. P. Purumal, Dr. J. Maheswaran "workability study on concrete with GGBS as a replacement material for cement with and without super plasticizer", International Journal of advanced Research in Engineering \& Technology, ISSN 09766480 (print), ISSN 0976-6499(Online) Vol. 3, Number 2, July-December 2012.

[20] Wang Ling, Tian Pei, and Yao Yan. (2004). "Application of Ground Granulated Blast Furnace Slag in High- Performance Concrete in China". International Workshop on Sustainable Development and Concrete Technology, Organized by China Building Materials Academy, PRC, 309-317. 